\title{
PRESENCE OF SPIROCHAETES IN PARESIS DESPITE PENICILLIN THERAPY*
}

\author{
BY \\ WALTER E. GAGER†, CHARLES W. ISRAEL , AND J. LAWTON SMITH \\ From the Department of Ophthalmology, University of Miami School of Medicine, Miami, Florida
}

The purpose of this report is to document the finding of spirochaetes in the cerebrospinal fluid, frontal lobe cortex, and liver in an autopsy proven case of general paresis despite a course of over 36 million units of penicillin. The patient died in the hospital of a pulmonary embolus while undergoing therapy and therefore was not exposed to reinfection.

\section{Case Report}

A 56-year-old right-handed Negro male was admitted to Jackson Memorial Hospital on May 28, 1967. His health had previously been satisfactory until that afternoon when he awoke from a nap with slurred speech and a left-sided paralysis.

Examination.-The blood pressure was 170/90; the patient was well nourished and reasonably alert, but had some dysarthria and a rather dense left hemiparesis. Some intermittent pronating movements of the left hand were seen. General examination was otherwise not remarkable.

Eye Examination (June 6, 1967).-The visual acuity was grossly intact, but a left homonymous hemianopia was present to confrontation. There was a rather sustained conjugate deviation of the eyes to the right, and left gaze was poorly maintained on command. The right pupil was $1.25 \mathrm{~mm}$. and the left $2 \mathrm{~mm}$. in diameter. The right pupil reacted moderately well to light, but the left showed only a trace response. Ophthalmoscopy showed the media to be clear and, but for moderate disc pallor, the fundi were considered normal.

Laboratory Studies.-The haemogram, urine analysis, serum electrolytes, and urea nitrogen were normal.

\footnotetext{
* Received for publication April 29, 1968.

+ Special Fellowship 1 F 11 NB 1792-01 VSN, National Institute of Neurological Diseases and Blindness.

₹ Special Fellowship 2 F 11 NB 1633-02 VSN, National Institute of Neurological Diseases and Blindness.

This work was supported in part by grants 5 RO 1 CC 00144-03, Communicable Disease Center; 5 RO 1 NB 06308-02, NB 05277-08, and 1 RO 1 NB 06574-02, National Institute of Neurological Diseases and Blindness.
}

Fasting blood sugars on two occasions were 157 and $173 \mathrm{mg}$. per cent. The serum VDRL test was reactive to 16 dilutions. The fluorescent treponemal antibody absorbed (FTA-ABS) test was strongly reactive.

Two attempts at lumbar puncture were unsuccessful because of arthritic changes, and a cisterna magna puncture was performed by Dr Shafey on May 30, 1967. The cerebrospinal fluid was clear and colourless, and contained 562 erythrocytes and 231 leukocytes per cu. mm.; the latter were 51 per cent. polymorphonuclears and 49 per cent. monocytes. Total protein 50 mg. per cent. Colloidal gold curve 4555432100. Cerebrospinal fluid VDRL and FTA-ABS tests were both reactive.

Routine skull $x$ rays showed normal appearances. A brain scan was positive for a right-sided lesion, but bilateral carotid arteriograms performed later were considered to be within normal limits.

Electroencephalography revealed bilateral posterior changes.

An electrocardiogram disclosed a complete left bundle branch block.

Close questioning of the patient elicited the history that at the age of 28 he had received injections for 3 months for a venereal infection.

Diagnosis.-Meningovascular syphilis with an acute left hemiplegia.

Treatment.-Antibiotic therapy was initiated as outlined in Table I.

\section{TABLE I}

ANTIBIOTICS ADMINISTERED DURING HOSPITALIZATION FROM MAY 28, 1967, TO DATE OF DEATH

\begin{tabular}{|c|c|c|}
\hline Antibiotic & $\begin{array}{c}\text { Dates } \\
\text { Administered }\end{array}$ & Total Dosage \\
\hline Ampicillin (Polycillin) & $29-5-67$ to $2-6-67$ & 9.0 g. \\
\hline $\begin{array}{l}\text { Aqueous Penicillin } \\
\text { Procaine Penicillin }\end{array}$ & $\begin{array}{l}2-6-67 \text { to } 5-6-67 \\
6-6-67 \text { to } 12-6-67\end{array}$ & $\begin{array}{l}7,800,000 \text { units } \\
14,400,000 \text { units }\end{array}$ \\
\hline Total & 29 May to 12 June & $36,600,000$ units \\
\hline
\end{tabular}

* Using $250 \mathrm{mg}$. equal to 400,000 units equivalency. 
Progress.-The cisternal tap was repeated on June 2, 1967, and a clear colourless fluid was obtained, with 1900 erythrocytes and 94 leukocytes per cu. mm., the latter being 97 per cent. monocytes. Total protein $53 \mathrm{mg}$. per cent. India ink preparations and cultures were negative for bacteria and fungi. The cerebrospinal fluid was examined with the fluorescent antibody stain, and a spirochaete of typical morphology was found which glowed brightly under ultraviolet light with tagged anti-Treponema pallidum globulin.

Termination.-The patient appeared to be improving clinically on penicillin therapy, but on the fourteenth hospital day, on going to the bathroom, he suddenly became dyspnoeic and cyanotic, and he then died.

Autopsy. - A complete post mortem examination was performed, and we are indebted to the Pathology Department for providing a copy of the report. Death had been caused by multiple, bilateral acute pulmonary emboli. The heart weighed $510 \mathrm{~g}$. and showed left ventricular hypertrophy.

Neuropathological examination of the brain (performed by Dr Edmund Mackey) showed the classical morphological changes of paresis. Microscopical examination revealed typical perivascular foci of inflammatory reaction with atrophy of the cerebral neural cells in diffuse patches. An iron stain revealed perivascular and intracellular phagocytosed deposits of iron. Diffuse hypertrophy and hyperplasia of microglial cells was noted.

\section{Discussion}

A diagnosis of meningovascular syphilis was made in the case of a patient who presented the clinical picture of a left-sided stroke. He had a history of venereal contact and positive serological tests for syphilis. Fluorescent antibody studies revealed Treponema pallidum in the cerebrospinal fluid. Immediate massive antibiotic treatment was undertaken. The patient died unexpectedly on the fourteenth hospital day.

Post mortem examination revealed left ventricular hypertrophy, a large laminated clot in the right femoral vein, and acute massive pulmonary embolism as the cause of death. Gross and microscopic examination of the brain revealed the typical histological changes of paresis. These are summarized in Table II (opposite).

Fig. 1 shows the typical perivascular lymphocytic and plasma cell infiltration seen in the brain.

Another characteristic histological change in general paresis is the hyperplastic microglial cell.

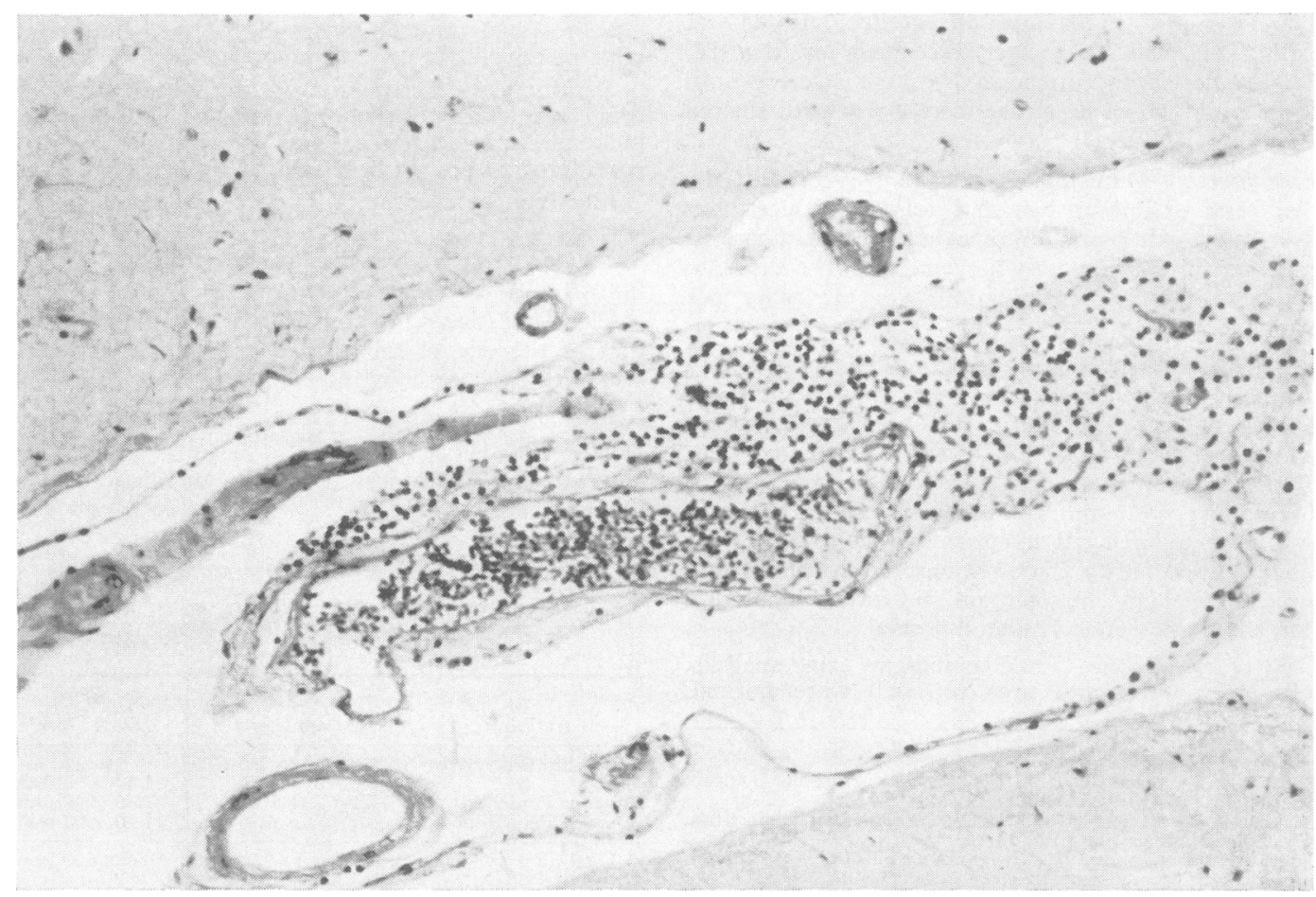

FIG. 1.-Perivascular leucocytic infiltration in the brain, typical of general paresis. $\times 200$. 
TABLE II

PATHOLOGY OF PARETIC NEUROSYPHILIS (Merritt, Adams, and Solomon, 1946)

\begin{tabular}{|c|c|}
\hline Macroscopic & $\begin{array}{l}\text { 1. Thickened and opaque meninges. } \\
\begin{array}{l}\text { 2. Cerebral atrophy (a) Widening of sulci. } \\
\text { (b) Dilatation of ventricles. }\end{array} \\
\text { 3. Granular ependymitis. }\end{array}$ \\
\hline Microscopic & $\begin{array}{l}\text { 1. Meningeal and perivascular infiltrates } \\
\text { (lymphocytes and plasma cells). } \\
\text { 2. Loss of and degeneration changes in nerve } \\
\text { cells. } \\
\text { 3. Reaction of microglial cells (rod cells) and } \\
\text { astrocytes. } \\
\text { 4. Deposition of iron pigment. } \\
\text { 5. Presence of spirochaetes. }\end{array}$ \\
\hline
\end{tabular}

To this cellular form Nissl gave the name "Stabchenzel" or rod cell. An example from this case is seen in Fig. 2. The rod cell is found in abundance in the degenerating cortical nerve tissues of the paretic. The nuclei are oriented perpendicularly to the surface of the brain, and are elongated and greatly increased in size and number. The cytoplasm is pale and the cell wall is visible with the common aniline dyes.

Pathognomic of the changes of general paresis are the perivascular and intracellular, phagocytosed deposits of iron (Figs 3 and 4, overleaf). These changes were first described by Bonfiglio (1911). The deposits are easily demonstrated by any standard iron stain. They are never found in normal tissue and differ markedly from the iron found after haemorrhage. The origin of these iron deposits has not been established. The Spatz (1922) test is a method of detecting iron in the brain that can be used at autopsy. A small piece of cerebral tissue is washed in normal saline and then immersed in concentrated ammonium sulphide for 15 minutes. With glass instruments, the tissue is transferred to a glass slide and pressed down with a cover slip. The appearance of small black dots is considered diagnostic of general paresis.

Noguchi and Moore (1913) were the first to describe spirochaetes in the cerebral cortex of patients with general paresis. Demonstration of this organism is accomplished by fluorescent antibody staining or the meticulous use of one of the many silver impregnation techniques. Spirochaetes that fluoresced brightly were identified after specific indirect immunofluorescent staining of fresh frozen sections of brain and liver tissue. Their morphology was characteristic of Treponema pallidum. Utilizing

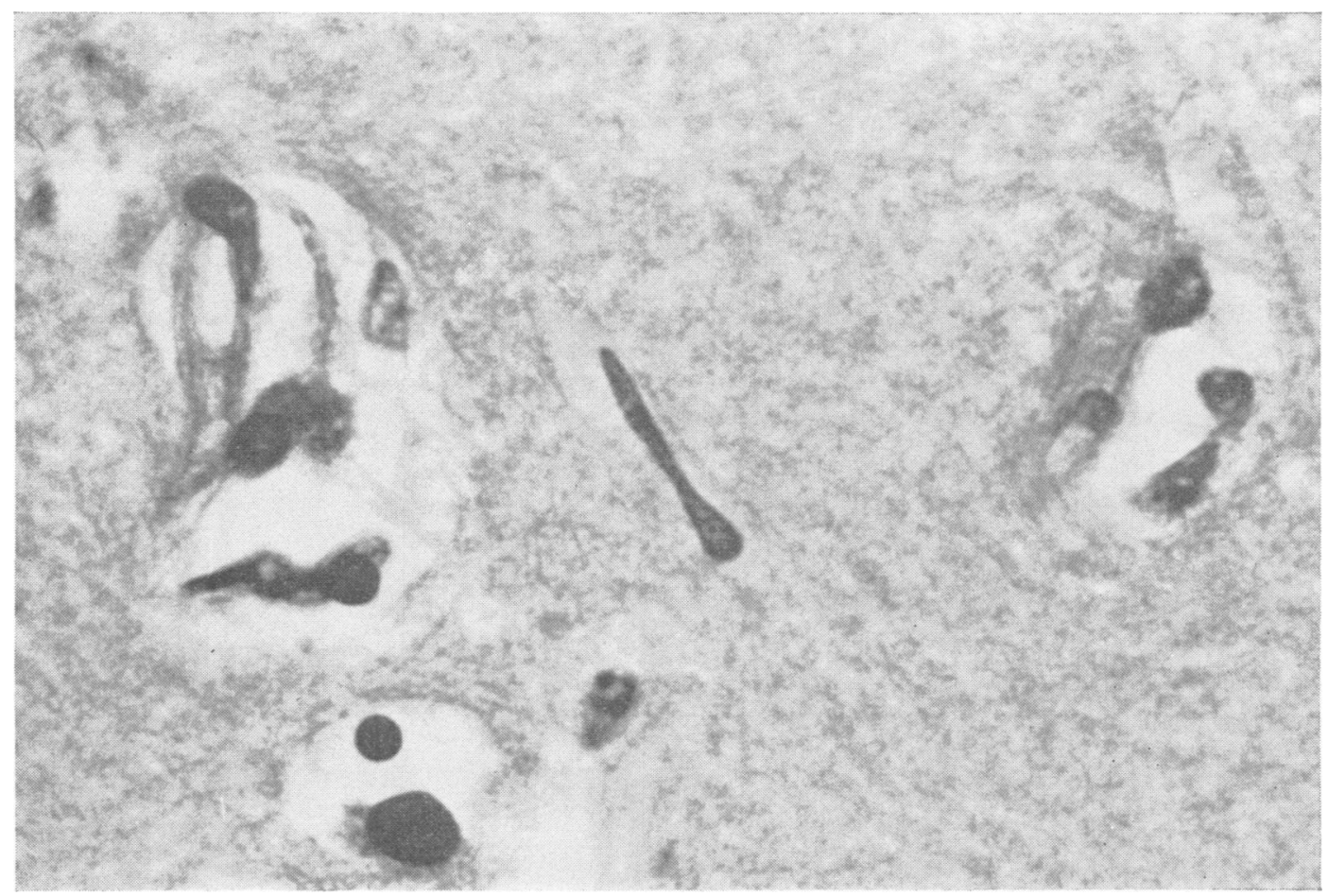

FIG. 2.-A typical rod cell, the hyperplastic and hypertrophic microglial cell classically found in paresis, $\times \mathbf{4 2 6}$, 


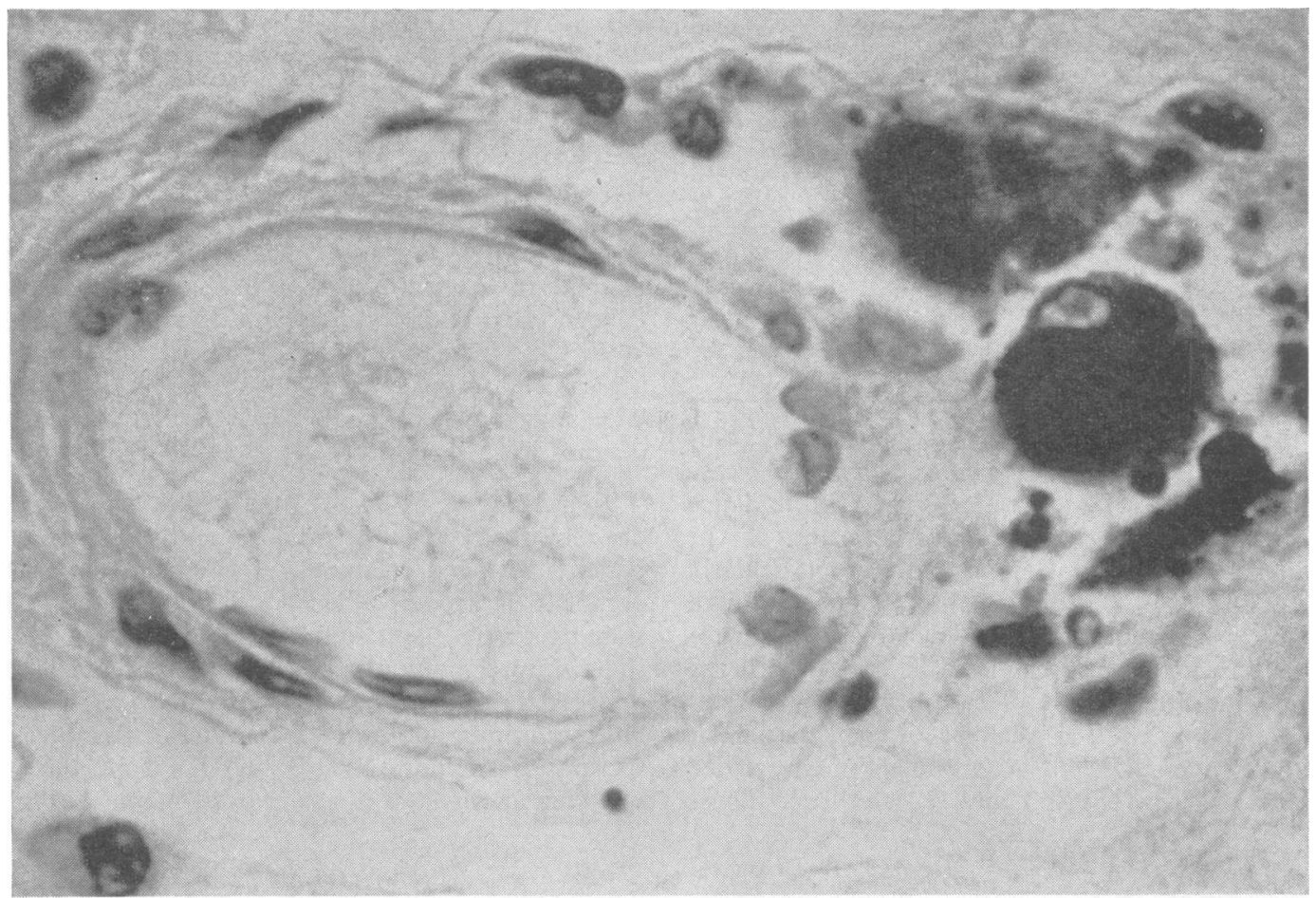

Fig. 3.-Cross-section of cerebral vessel to show the intracellular and extracellular deposition of iron. Iron stain. $\times 426$.

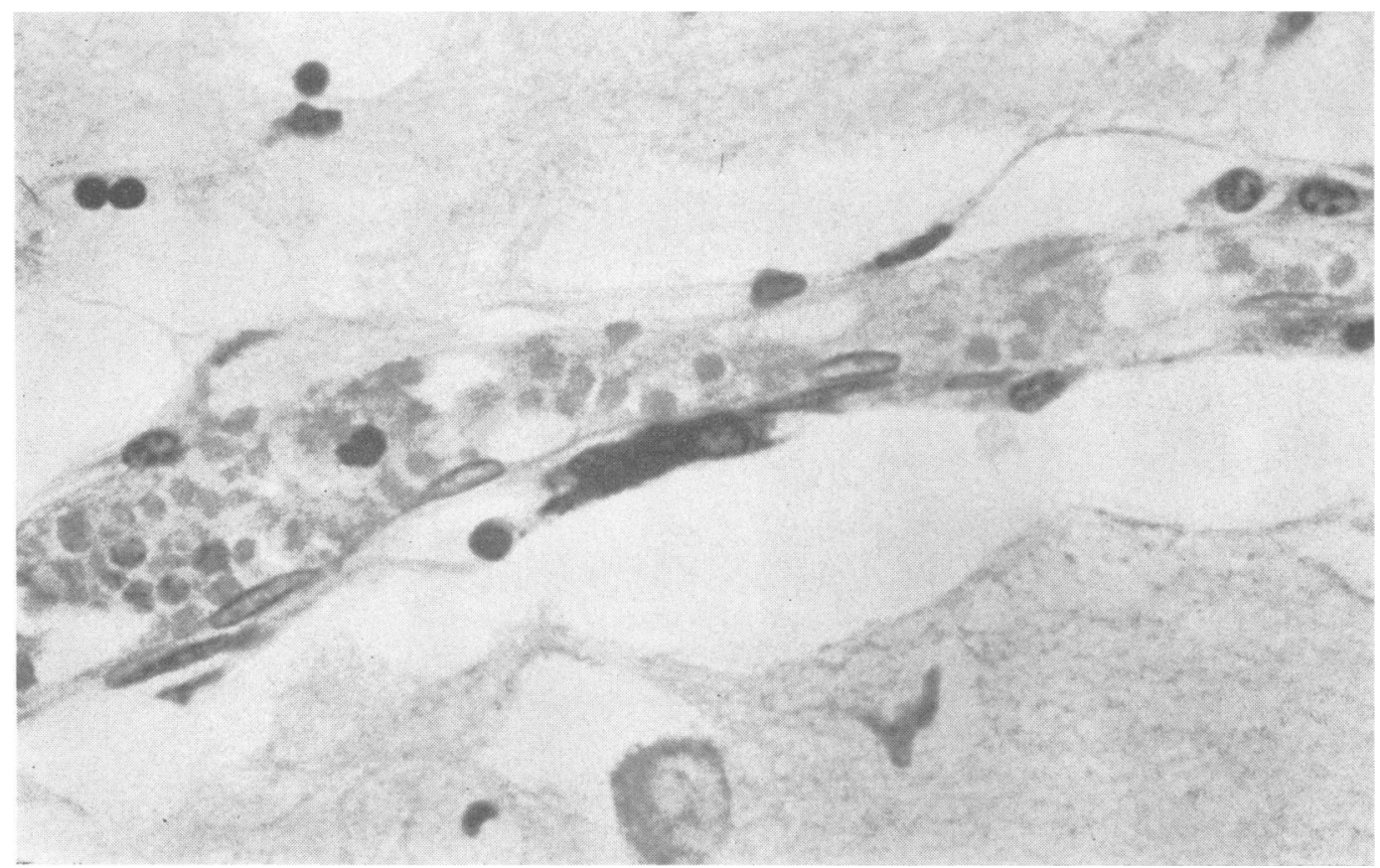

FIG. 4.-Longitudinal section of a blood vessel to demonstrate the perivascular deposition of iron. $\times 426$. 


\section{PRESENCE OF SPIROCHAETES IN PARESIS DESPITE PENICILLIN THERAPY 281}

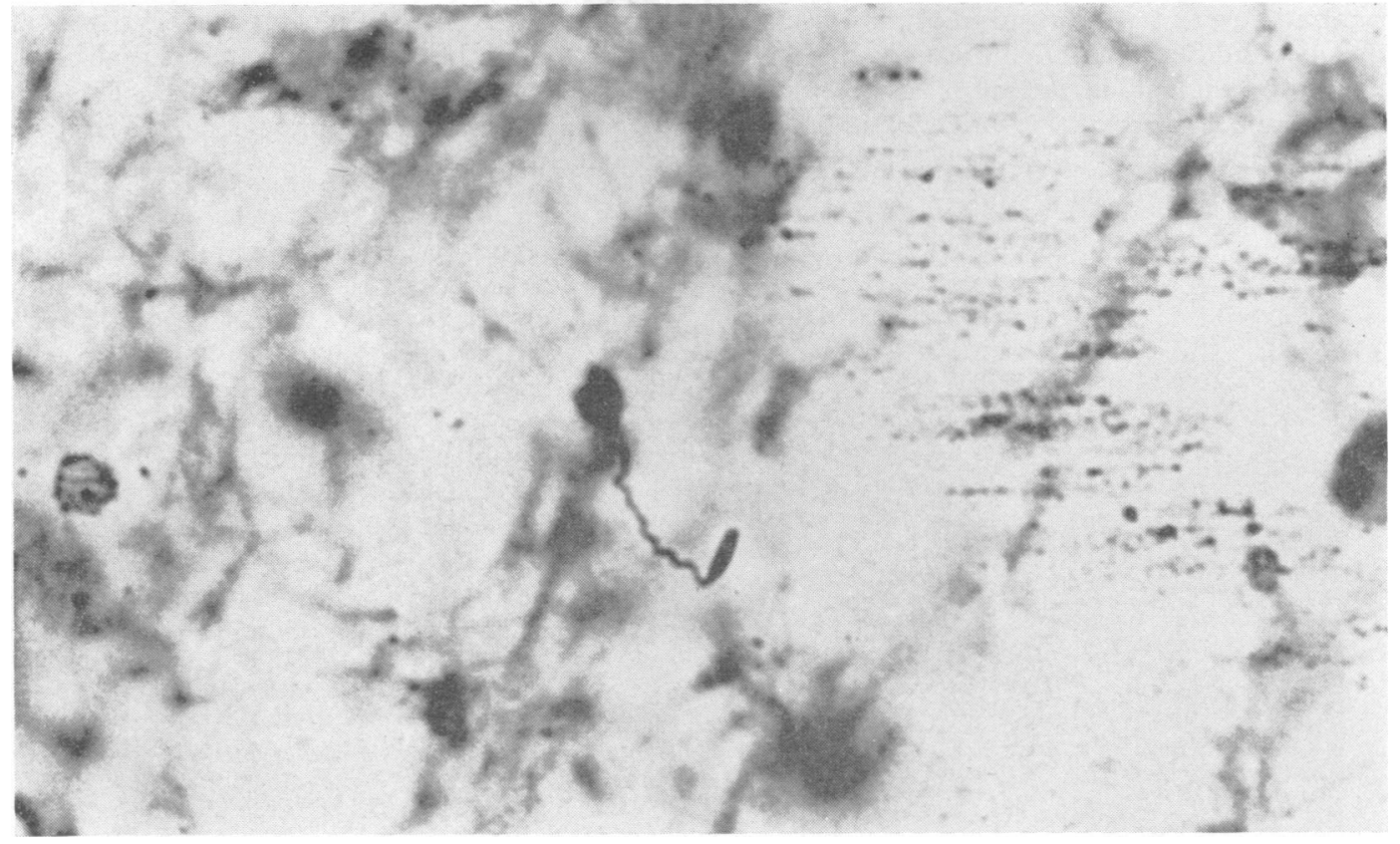

FIG. 5.-Spirochaete found in the frontal lobe of this patient. Krajian silver impregnation. $\times 426$.

the Krajian (1939) silver impregnation method, numerous spiral organisms were identified in the frontal lobe cortex (Fig. 5) and liver (Fig. 6).
A particularly interesting morphological form of Treponema pallidum is seen in Fig. 5. This spirochaete shows a terminal bud or granule-a classically

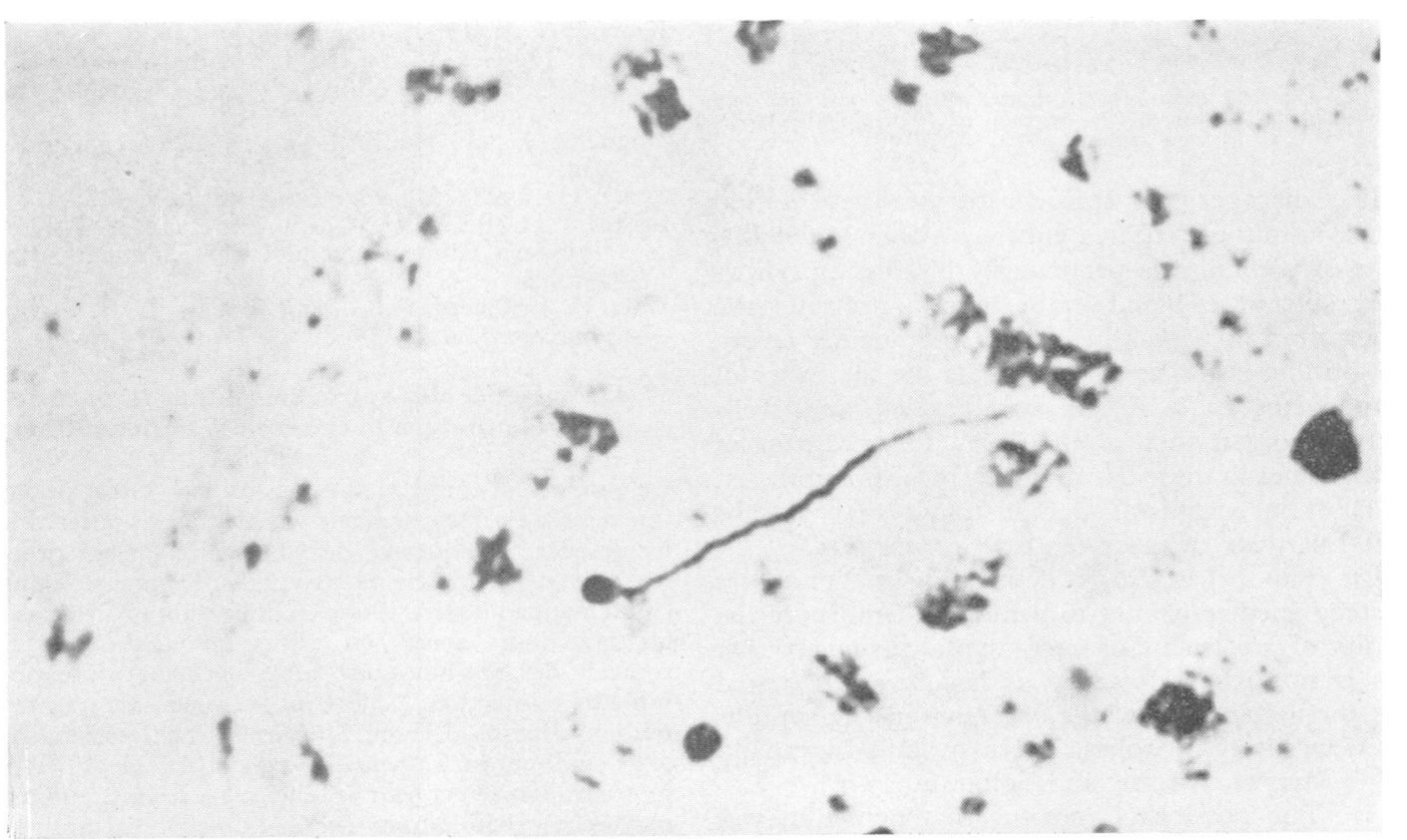

FIG. 6.-Spirochaete found in the liver of this patient. Krajian silver stain. $\times 426$. 
recognized form of the organism. First described by Jacquet and Sézary (1907), it was again reported by such prominent investigators as Hoffmann, Hoffman, and Mulzer (1927) (Fig. 7), and Collart (1964). Furthermore, this knoblike structure was noted during electron microscopic studies by Wile, Picard, and Kearny (1942).

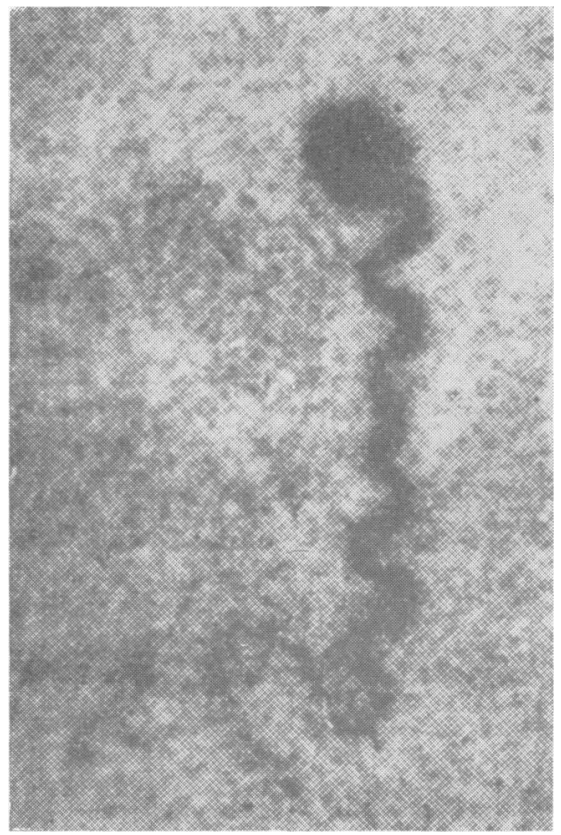

Fig. 7.-Classical form of spirochaete with the terminal bud (Hoffman, and others, 1927)-reproduced from Collart, 1964. approx. $600 \times$.

The discovery of spirochaetes in the cerebral cortex at autopsy after a course of over $36,000,000$ units of penicillin is particularly interesting. However, since the blood-brain barrier prevents the penetration of penicillin in high therapeutic levels, this finding is not as significant as the discovery of spirochaetes in a highly vascularized and wellperfused organ such as the liver. The presence of spirochaetes in these tissues raises three possibilities:

(1) The organisms demonstrated may not be alive but their delicacy tends to refute this.

(2) The organism is developing a heretofore unrecognized resistance to penicillin. Studies of the results of treatment of early syphilis suggest that this is not true. However, it has been suggested that the metabolism of the organism in late syphilis has been altered (Stokes, Beerman, and Ingraham, 1944; Merritt, Adams, and Solomon, 1946).

(3) The possibility remains that penicillin was administered over too short a period of time. If the metabolism of the treponeme has changed after many years in its human host, the period between divisions could also have lengthened. This might suggest that antibiotics should be given over a prolonged period of time.

\section{Summary}

This report documents a histopathologically proven case of general paresis in which the historical, clinical, and laboratory findings were commensurate with the diagnosis of syphilis. The patient died suddenly in the hospital of a massive pulmonary embolus on the fourteenth hospital day while receiving antibiotics, thus precluding the possibility of re-infection. Despite a course of over 36 million units of penicillin, spirochaetes with morphology typical of $T$. pallidum were identified post mortem in both the brain and liver. The need for further anatomical investigation of cases of treated late syphilis is evident.

\section{REFERENCES}

Bonfiglio, G. (1911). Z. ges. Neurol. Psychiat., 3, 718.

Collart, P. (1964). In "Proceedings of the World Forum on Syphilis and Other Treponematoses", Public Health Serv. Publ. No. 997, p.285. Washington, D.C.

Hoffmann, E., Hofman, E., and Mulzer, P. (1927). In "Handbuch der Haut- und Geschlechtskrankheiten", ed. J. Jadassohn, vol. 15, pt.1. Springer, Berlin.

Jacquet, L., and Sézary, A. (1907). Bull. Soc. méd. Hôp. Paris, 3 sér., 24, 114.

Krajian, A. A. (1939). Amer. F. Syph., 23, 617.

Merritt, H. H., Adams, R. D., and Solomon, H. C. (1946). "Neurosyphilis". Oxford University Press, New York.

Noguchi, H., and Moore, J. W. (1913). F. exp. Med., 17, 232.

Spatz, H. (1922). Münch. med. Wschr., 69, 1376.

Stokes, J. H., Beerman, H., and Ingraham, N. R. (1944) "Modern Clinical Syphilology". Saunders, Philadelphia.

Wile, U. J., Picard, R. G., and Kearny, E. B. (1942). F. Amer. med. Ass., 119, 880.

La présence des spirochètes dans la parésie générale malgré la thérapie à la pénicilline RÉSUMÉ

Ce rapport documente un cas, prouvé histopathologiquement, de parésie générale dans lequel les observations historiques, cliniques et de laboratoire étaient proportionnées au diagnostic de la syphilis. Le malade mourut subitement à l'hôpital d'une embolie pulmonaire massive quatorze jours après son admission et pendant qu'il recevait des antibiotiques, ainsi excluant toute possibilité de réinfection. Malgré un traitement de plus de 36 millions d'unités de pénicilline, les spirochètes à morphologie typique du $T$. pallidum avaient été identifiés post mortem dans le cerveau et le foie. La nécessité d'autres recherches anatomiques des cas de syphilis tardive est évidente. 